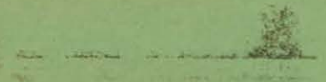

5240-3, Rev. A

Photovoltaics Program

Technology Development and Applications Lead Center
DOE/ET-20356-1, Rev. 1

Distribution Category UC-63b

\title{
MASTER
}

\section{Photovoltaic-Systems Test Facilities: Existing Capabilities Compilation}

\author{
DO NOT MICROFILM \\ COVER
}

March 1, 1982

Prepared for

U.S. Department of Energy

Through an Agreement with

National Aeronautics and Space Administration

by

Jet Propulsion Laboratory

California Institute of Technology

Pasadena, California

(JPL PUBLICATION 81-14, REVISION 1) 


\section{DISCLAIMER}

This report was prepared as an account of work sponsored by an agency of the United States Government. Neither the United States Government nor any agency Thereof, nor any of their employees, makes any warranty, express or implied, or assumes any legal liability or responsibility for the accuracy, completeness, or usefulness of any information, apparatus, product, or process disclosed, or represents that its use would not infringe privately owned rights. Reference herein to any specific commercial product, process, or service by trade name, trademark, manufacturer, or otherwise does not necessarily constitute or imply its endorsement, recommendation, or favoring by the United States Government or any agency thereof. The views and opinions of authors expressed herein do not necessarily state or reflect those of the United States Government or any agency thereof. 


\section{DISCLAIMER}

Portions of this document may be illegible in electronic image products. Images are produced from the best available original document. 
Technology Development and Applications

Lead Center

\section{Photovoltaic Systems Test Facilities: Existing Capabilities Compilation}

Prepared for

U.3. Department of Encrgy

Through an Agreement with

National Aeronautics and Space Administration

by

Jet Propulsion Laboratory

California Institute of Technology

Pasaderla, Cadifumia

(JPL PUBLICATION 81-14, REVISION 1) 
Prepared by the Jet Propulsion Laboratory, California Institute of Technology, for the U.S. Department of Energy through an agreement with the National Aeronautics and Space Administration.

This report was prepared as an account of work sponsored by an agency of the United States Government. Neither the United States Government nor any agency thereof, nor any of their employees, makes any warranty, express or implied, or assumes any legal liability or responsibility for the accuracy, completeness, or usefulness of any information, apparatus, product, or process disclosed, or represents that its use would not infringe privately owned rights.

Reference herein to any specific commercial product, process, or service by trade name, trademark, manufacturer, or otherwise, does not necessarily constitute or imply its endorsement, recommendation, or favoring by the United States Government or any agency thereof. The views and opinions of authors expressed herein do not necessarily state or reflect those of the United States Government or any agency thereof.

Work conducted through NASA Task RD-152, Amendment 200 and Sponsored by the U.S. Department of Energy under Interagency Agreement DE-AI01-76ET20356. 


\section{ABSTRACT}

Photovoltaic Systems Test Facilities (PV-STFs) are used to evaluate complete photovoltaic systems, subsystems, and their interfaces. This report presents a general description of PV-STFs presently operated under the U.S. Department of Energy's National Photovoltaics Program, as well as descriptions of a number of privately operated facilities reflecting current understanding of those having test capabilities appropriate to PV hardware development. A summary of specific, representative test capabilities at the system and subsystem level is presented for each listed facility. This compilation indicates the range of system and subsystem test capabilities presently available to serve the needs of both the National Photovoltaics Program and the private sector photovoltaics industry. 


\section{THIS PAGE}

\section{WAS INTENTIONALLY}

LEFT BLANK 
EXECUTIVE SUMMARY . . . . . . . . . . . . . . . . . . . . . . 1

I. INTRODUCTION ......................... . . . . . .

A. BACKGROUND .. . . . . . . . . . . . . . . . . . 1-1

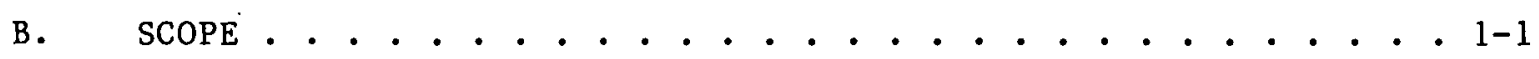

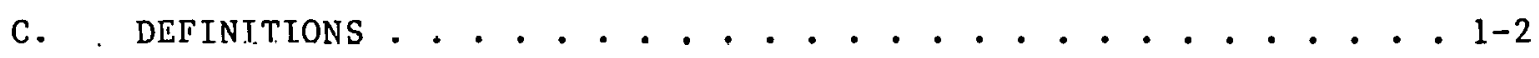

II. PhotovoltaIC SYSTEMS TEST FACILITY DESCRIPTION . . . . . . . . . . 2-1

A. CHARACTERISTICS OF THE PHOTOVOLTAIC SYSTEMS TEST FACILITY . • . 2-1

B. Photovoltaic SyStems test FACILITy IMPLEMENTATion . . . . . . 2-1

III. Photovoltaic Systems test faCilities: EXISTing CAPABilities . . . $3-1$

\section{Figure}

2-1. Generalized Photovoltaic System . . . . . . . . . . . 2-1

\section{Tables}

1. Facility Information: U.S. DOE Photovoltaics

Program Centers . . . . . . . . . . . . . . . . 2

2. Photovoltaic Test Facilities: Private Laboratories . . . . 3

3-1. General Facility Information: U.S. DOE Photovoltaics

Program Centers.................. . . 3-2

3-2. General Facility Information: Private Laboratories . . . . 33

3-3. Systems Test Capabilities: Photovoltaics Program Centers . . 3-4

3-4. Collector Test Capabilities: Photovoltaics Program Centers . . 3-5

3-5. Power Conditinner Test Capabilities: Photovoltaics Program

Centers......................... 3-8

3-6. Storage Test Capabilities: Photovoltaics Program Centers... 3-11

3-7. Collector Test Capabilities: Private Laboratories . . . . 3-12

3-8. Power Conditioner Test Capabilities: Private Laboratories . 3-15

3-9. Storage Test Capabilities: Private Laboraturies . . . . . 3-18 
To meet the objectives of the U.S. Department of Energy's National Photovoltaics Program, a number of evaluation, environmental, and performance tests of photovoltaic systems, subsystems, and major system components will be required during the next several years. This report is a description of test facilities identified as currently available to support anticipated Program system-level test activities. It also lists test capabilities at the subsystem and major component levels where these activities directly support programmatic system test requirements. Many of these facilities are presently available to support photovoltaics development activities within the private sector. 1

Eleven test installations have been identified and surveyed to provide data summarizing their test capabilities. Of the eleven queried, four are Photovoltaics Program centers and seven are private testing laboratories. Tables 1 and 2 present an overview of these facilities.

Several other test facilities were identified as having PV-related test capabilities. These include the Florida Solar Energy Center, Hawaii Natural Energy Institute, Southern Solar Energy Center, and the Southwest Research Institute. These facilities have not been detailed in the present document, either because their availability to the Program is uncertain, or their emphasis is upon thermal technologies, "outside-the-fence" testing, or product certification. The latter activities lie beyond the scope of the current Photovoltaics Program.

The four Photovoltaics Program centers presently operate facilities with system-level test capabilities. This means that complete photovoltaic systems, consisting of array, power processing units, controls, and storage where appropriate, can be installed and operated to permit evaluation of system performance characteristics in a realistic environment. The Program centers also operate facilities for testing separate subsystems. Taken together, the system and subsystem level test results permit verification of system and subsystem design, performance, and interface requirements, as well as validation of performance models and design methodologies.

The private laboratories surveyed report test capabilities covering a wide range of environmental and accelerated life testing appropriate to the development requirements of photovoltaic subsystems and components. Although none of these laboratories presently exhibit system-level test capability, these facilities nevertheless represent a substantial resource available to support important clements of the nverall system development effort.

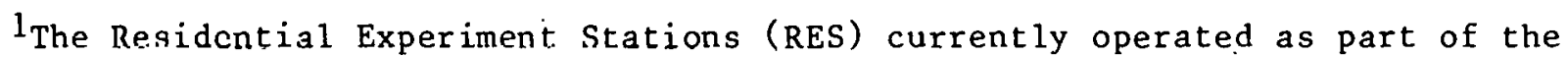
Photovoltaics Program have not been included in this compilation. The RESs were established for the purpose of conducting operational experiments on a set of prototype systems of fixed configurations. The System Test Facility (STF) is designed to accept and test systems and subsystems in a manner which permits frequent configuration changes. The two existing kESs may evelltially be adapted for more general use as STFs. Options presently under consideration include their direct availability for use by private industry. 
Table. 1. Facility Information: U.S. DOE Photovoltaics Program Centers

\begin{tabular}{llc}
\hline Managing Agency & Location & Applicationa \\
\hline Jet Propulsion Laboratory & Pasadena, California & RS, R, I \\
Lewis Research Center & Cleveland, Ohio & RS (U) \\
MIT/Lincoln Laboratory & Lexington, Massachusetts & RS, R, I (U) \\
Sandia National Laboratories & Albuquerque, New Mexico & RS, R, I CS (U) \\
\hline $\begin{array}{l}\text { a }- \text { Remote - Stand Alone } \\
\text { R - Residential } \\
\text { I - Intermediate } \\
\text { CS - Central Station } \\
\text { (U) - Utility Interface Capability }\end{array}$ \\
\hline
\end{tabular}


Table 2. Photovoltaics Test Facilities: Private Laboratories

\begin{tabular}{|c|c|c|}
\hline Company & Location & Comments \\
\hline Acton Energy Laboratory & Acton, Massachusetts & $\begin{array}{l}\text { Test procedures are generated using customer- } \\
\text { provided test plans. Solar thermal experience. } \\
\text { Facility size: } 3200 \mathrm{~m}^{2}\end{array}$ \\
\hline $\begin{array}{l}\text { Approved Engineering } \\
\text { Test Laboratories }\end{array}$ & Encino, California & $\begin{array}{l}\text { A general purpose environmental test laboratory; } \\
\text { sand, dust, vibration, shock, etc. AETL is a } \\
\text { division of National Technical Services Co. and } \\
\text { has five sites in southern California with varying } \\
\text { capabilities and size }\end{array}$ \\
\hline $\begin{array}{l}\text { AVCO Environmental } \\
\text { Testing Laboratories }\end{array}$ & Wilmington, Massachusetts & $\begin{array}{l}\text { Environmental testing capabilities include climatic } \\
\text { test facilities for temperature, humidity, salt } \\
\text { fog, sand; dust, and fungus; AVCo has other general } \\
\text { environmental test capabilities, including a } \\
\text { seismic test Eacility }\end{array}$ \\
\hline DSET Laboratories, Inc. & Phoenix, Arizona & $\begin{array}{l}\text { Performance, reliability and durability testing of } \\
\text { photovoltaic materials, components, and subsystems. } \\
\text { Solar measurements; radiometric measurements of } \\
\text { artificial light sources. Six remote sites and a } \\
\text { seventh planned }\end{array}$ \\
\hline Franklin Research Center & Philadeiphia, Pennsylvania & $\begin{array}{l}\text { Non-proft. Facility size: } 19,000 \mathrm{~m}^{2} \text {. Experi- } \\
\text { ence relative to tracking and control of electrical } \\
\text { output and utility interface. Some research } \\
\text { relative to development of thermal collectors }\end{array}$ \\
\hline $\begin{array}{l}\text { Structural Dynamics } \\
\text { Research Corp. }\end{array}$ & Milford, Ohio & $\begin{array}{l}\text { Facility size: } 800 \mathrm{~m}^{2} \text {. Mechanical and struc- } \\
\text { tural engineering consulting company; primarily } \\
\text { failure and fatigue through analysis and testing. }\end{array}$ \\
\hline Wyle Laboratories & Huntsville, Alabama & $\begin{array}{l}\text { Environmental testing capabilities include } \\
\text { accelerated power conditioner testing to } 27 \mathrm{~kW} \mathrm{DC} \text {; } \\
\text { load capability to } 100 \mathrm{~kW}\end{array}$ \\
\hline
\end{tabular}




\title{
SECTION I
}

\author{
INTRODUCTION
}

\section{A. BACKGROUND}

In the development of new sources of energy for the United States, assessment of the terrestrial photovoltaic (PV) option has been only recently initiated. As in most new technology programs, early PV system development efforts have relied extensively on modeling and simulation to assist in designing operational systems prior to their deployment. Despite such analyses, any newly-developed technology may experience unforeseen problems, particularly in the interactions between subsystems, and between the system and the operating environment. To identify and address such problems prior to actual system deployment, some form of testing and evaluation of full-scale prototype systems under realistic operating conditions is essential.

In recognition of this need, an early step taken by the National Photovoltaics Program was to initiate a planning activity whose purpose was to ensure the availability of test facilities adequate to the requirements of the Program. Participating in this activity were representatives of the principal Program centers involved in photovoltaic technology development and testing.

One of the first steps taken in this planning process was to compile information about PV systems test facilities both available for, and appropriate to, the specific testing requirements of Program-sponsored system development efforts. Included were facilities within the Photovoltaics Program centers, as well as state-supported and private facilities. The first STF Existing Capabilities Compilation, issued by the Jet Propulsion Laboratory in August 1981, summarized the collected PV-STF information and addressed the question of future Photovoltaics Program PV-STF requirements.

The present compilation has been updated to reflect recent substantial revisions in the National Photovoltaics Program structure and funding level. The current Photovoltaics Program is based on (1) an allocation of resources which will require the pursuit of considerably fewer technology options, (2) technology transfer to the private sector at an earlier stage of the development sequence, and (3) greater reliance on industry at all levels of technical decision-making. Accordingly, it should be noted that many of the facilities included in this revised compilation are currently available to the $P V$ industry at large, while continuing to serve those activities directly supported by the Program.

\section{B. SCOPE}

The PV-STF characteristics summarized herein include the test capabilities of primary interest in the development of photovoltaic systems for all appplications areas: remote stand-alone, small roof-mounted, 
medium-size, and large ground-mounted systems. Test capabilities are characterized as follows:

(1) Facility capacity/rating: maximum power handling capability, thermal capacity, storage capacity, etc.

(2) Test level: total system, subsystem, or major system component.

(3) Capacity to test in grid-connected mode, stand-alone, or both.

(4) Specific measurement capability as to type and capacity, where applicable.

This compilation lists several facilities whose primary capabilities are in subsystem and component testing (environmental and accelerated life). Although not strictly a part of system-level testing, subsystem and component testing constitute important elements of the overall system development process. Additionally, most testing of established products is performed at the subsystem and component levels. As more is learned about PV systemsubsystem interactions and how to better model and simulate those interactions, testing at the subsystem and component levels is expected to assume an increasingly important role relative to system-level testing.

\section{DEFINITIONS}

Terms used in this compilation are defined below:

(1) Photovoltaic Systems Test Facility (PV-STF): A facility that tests and evaluates the performance of total PV systems, subsystems, and their interfaces.

(2) Subsystem Test Facility: A facility that tests and evaluates the performance of PV subsystems. Currently, there are three subsystems: array, power processing, and energy storage.

(3) Component Test Facility: A facility that tests and evaluates the performance of major PV system components, such as PV modules and inverters, which are elements of subsystems. Component testing includes environmental and accelerated-life testing.

(4) Environmental Testing: Testing that attempts to identify the mechanisms of failure caused by extremes of loads induced by environmental forces, either acting alone or in combination.

(5) Accelerated-Life Testing: Testing that attempts to accelerate long-term degradation effects and, in so doing, correlate that degradation with time.

(6) Program Center Test Facilities: Facilities that are directly. owned or sponsored by the Federal Government and are a part of the National Photovoltaics Program. 
(7) Non-Programmatic Facilities: Test facilities that are either owned and operated by a state or agency thereof or are privately owned. These facilities are available to the Program on a contract basis as required. 


\section{PHOTOVOLTAIC SYSTEMS TEST FACILITY DESCRIPTION}

\section{A. CHARACTERISTICS OF THE PHOTOVOLTAIC SYSTEMS TEST FACILITY}

For purposes of this document, the principal characteristic of the PV-STF that distinguishes it from a typical full-scale system demonstration is that the facility is adaptable to a variety of PV system configurations, rather than dedicated to the evaluation of a single, specific design. Ideally, a PV-STF will be able to test various combinations of PV modules and arrays, including flat-plate or concentrator, PV and thermal, (whether side-by-side or combined), and accommodate either stand-alone or grid-interactive system designs. Additionally, the PV-STF should be capable of accepting configuration changes rapidly enough to permit practical retesting and evaluation. This latter characteristic is termed "breadboarding."

\section{B. PHOTOVOLTAIC SYSTEMS TEST FACILITY IMPLEMENTATION}

The following are key elements in the implementation of PV-STFs:

(1) PV System Configuration: In its most general form, a photovoltaic (or more properly, photovoltaic/thermal) system is configured as shown in Figure 2-1. Both electrical and thermal systems are

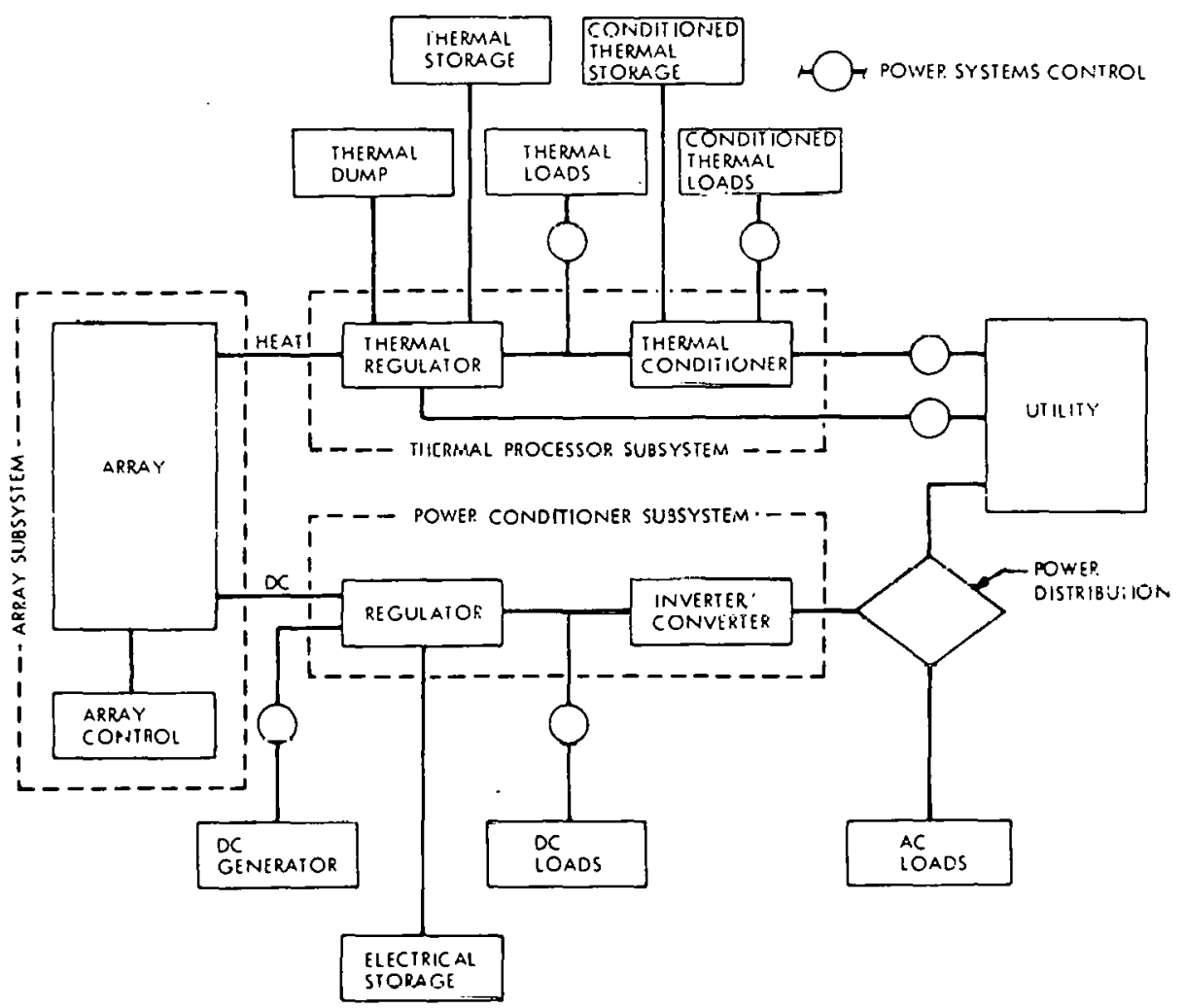

Figure 2-1. Generalized Photovoltaic System 
involved. It should be noted that current systems concepts for most applications are considerably simpler than this general configuration, involving only the electrical system elements. Medium-size system concepts (commercial and industrial

applications) presently exhibit the greatest diversity, due to the potential value of both electrical and thermal energy in this sector, and the potential for either concentrator or flat-plate designs. To support the development of a technology characterized by a large variety of practical system forms and applications, it is clearly of value for a PV-STF to be highly adaptable, allowing quick reconfiguration of its test bed to accommodate and test a different system once testing of a previous system is complete.

(2) Test Procedures and Equipment: In the development and comparative evaluation of multiple system concepts, commonality of test equipment and procedures is essential. With several PV-STFs in different climates testing a variety of photovoltaic systems, uniformity of test methods is essential to ensure valid comparison of results. The National Photovoltaics Program has supported the development of such test methods with the cooperation of private laboratories, industry, government, and public interest groups. The results to date appear in Interim Performance Criteria for Photovoltaic Energy Systems, a document published by the Solar Energy Research Institute. ${ }^{2}$ These results are expected to provide a uniform basis for subsequent development of industry-wide test procedures and standards for evaluation of PV systems.

(3) Data Acquisition and Processing: Typical kinds of information provided by a PV-STF include efficiency for various modes of operation, initial reliability estimates, transient response characteristics, assessment of system modeling and simulation, assessment of control strategies, and stability evaluation. Timely analysis and dissemination of the results of programmatic systems testing and evaluation performed in PV-STFs are expected to enhance the worth of these data.

2 Interim Performance Criteria for Photovoltaic Energy Systems, SERI/TR-742-654, R. DeBlasio, et. al., December 1980. This document, issued by the Solar Energy Research Institute, Golden, Colorado, for the U.S. Department of Energy, presents interim results of efforts "to identify, develop, and promulgate performance criteria and test methods for photovoltaic solar energy conversion systems." 
PHOTOVOLTAIC SYSTEMS TEST FACILITIES: EXISTING CAPABILITIES

This section summarizes, in tabular form, the information collected on PV system, subsystems, and major component testing facilities. Addressed are general facility information as well as representative testing capabilities. The information contained in the following tables is not intended as an exhaustive description of the capabilities of each facility, nor does it purport to indicate what tests are appropriate for particular system or subsystem development activities. Rather, the included information is intended primarily to illustrate the general range of capabilities provided by each facility. Inquiries regarding more specific test capability or facility availability should be directed to the appropriate facility contact (see Tables 3-1 and $3-2$ ).

The compiled information is contained in four sections, as follows:

(1) Summary Tables: Table 3-1 summarizes the information obtained for the National Photovoltaics Program Centers. Locations, contacts, application sector capabilities, maximum power handling capability and, where available, initial and annual costs are shown.

Table 3-2 summarizes the capabilities of private laboratories.

(2) System Test Capabilities: Table 3-3 delineates the capabilities of those facilities that have total system testing capacity. These capabilities are broken down by major subsystem; i.e., array, power conditioner, and storage.

(3) Subsystems Test Capabilities - Photovoltaics Program Centers: Tables 3-4 through 3-6 present detailed descriptions of the test capabilities of the Program field centers.

(4) Subsystems Test Capabilities - Private Laboratories: Tables 3-7 through 3-9 give a detailed description of the test capabilities of the private laboratories surveyed. 
Table 3-1. General Facility Information: U.S. DOE Photovoltaics Program Centers

\begin{tabular}{|c|c|c|c|c|c|c|}
\hline Managing Agency & Location & Phone/Contact & Application ${ }^{a}$ & $\begin{array}{l}\text { Maximuin } \\
\text { Power kW }\end{array}$ & $\begin{array}{c}\text { Initial Cost } \\
\$ K(\text { year) }\end{array}$ & $\begin{array}{c}\text { Annual } \\
\text { Cost, } \$ \mathrm{~K}\end{array}$ \\
\hline $\begin{array}{l}\text { Jet Propulsion } \\
\text { Laboratory }\end{array}$ & Pasadena, California & $\begin{array}{l}\text { (213) } 577-9440 \\
\text { R. Baisley } \\
\text { (213) 177-9161 } \\
\text { J. Graf }\end{array}$ & $\mathrm{RS}, \mathrm{R}, \mathrm{I}$ & 10 & & \\
\hline $\begin{array}{l}\text { Lewis Research } \\
\text { Center }\end{array}$ & Cleveland, Ohio & $\begin{array}{l}\text { (216) } 433-6295 \\
\text { (FTS) } 294-6295 \\
\text { W. Masica }\end{array}$ & RS . & 30 & . & \\
\hline $\begin{array}{l}\text { MIT/Lincoln } \\
\text { Laboratory }\end{array}$ & $\begin{array}{l}\text { Lexington, } \\
\text { Massachusetts }\end{array}$ & $\begin{array}{l}(617) \quad 362-5500 \\
\text { ext. } 7973 \\
\text { S. E. Forman }\end{array}$ & $\mathrm{RS}, \mathrm{R}, \mathrm{I}$ & 10 & $250(1978)$ & $50-65$ \\
\hline $\begin{array}{l}\text { Sandia National } \\
\text { Laboratories }\end{array}$ & $\begin{array}{l}\text { Albuquerque, } \\
\text { New Mexico }\end{array}$ & $\begin{array}{l}\text { (FTS) } 844-0112 \\
\text { H.J. Gerwin }\end{array}$ & $R S, R, I, C S$ & 150 & $500(1976)$ & 600 \\
\hline $\begin{array}{l}a_{R S} \text { - Remote - Stand } \\
\text { R - Residential } \\
\text { I - Internediate } \\
\text { CS - Central Station }\end{array}$ & ne & & & & & \\
\hline
\end{tabular}


Table 3-2. General Facility Information: Private Laboratories

\begin{tabular}{|c|c|c|c|}
\hline Company & Location & Phone/Contact & Comments \\
\hline $\begin{array}{l}\text { Acton Energy } \\
\text { Laboratory }\end{array}$ & $\begin{array}{l}533 \text { Main Street } \\
\text { Acton, Massachusetts } \\
01720\end{array}$ & $\begin{array}{l}\text { (617) 263-2933 } \\
\text { Mr. Russell Levin }\end{array}$ & $\begin{array}{l}\text { Test procedures are generated using customer-provided } \\
\text { test plans. Solar thermal experience. Facility } \\
\text { size: } 3200 \mathrm{~m}^{2}\end{array}$ \\
\hline $\begin{array}{l}\text { Approved Engineering } \\
\text { Test Laboratories } \\
\text { (AETL) }\end{array}$ & $\begin{array}{l}15720 \text { Ventura Blvd. } \\
\text { Encino, California } \\
91436\end{array}$ & $\begin{array}{l}(213) 783-5985 \\
\text { Mr. A. Edelstein, or } \\
(213) 306-3994 \\
\text { Mr. David Pelk }\end{array}$ & $\begin{array}{l}\text { A general purpose environmental test laboratory; } \\
\text { sand, dust, vibration, shock, etc. AETL is a divi- } \\
\text { sion of National Technical Services Co. Capabilities } \\
\text { vary from site to site. AETL has five sites in } \\
\text { southern California with varying capabilities and } \\
\text { size }\end{array}$ \\
\hline $\begin{array}{l}\text { AVCO Environmental } \\
\text { Testing Laboratories }\end{array}$ & $\begin{array}{l}201 \text { Lowell Stree: } \\
\text { Wilmington, } \\
\text { Massachusetts }\end{array}$ & $\begin{array}{l}(617) \quad 657-2222 \\
\text { Mr. Harry Zoglia } \\
\text { Mr. Al Koch }\end{array}$ & $\begin{array}{l}\text { Environmental testing capabilities include climatic } \\
\text { testing facilities for temperature, humidity, salt } \\
\text { fog, sand, dust, and fungus }\end{array}$ \\
\hline $\begin{array}{l}\text { DSET Laboratories, } \\
\text { Inc. }\end{array}$ & $\begin{array}{l}\text { Box } 1850 \\
\text { Black Canyon Stage } \\
\text { Phoenix, Arizana } \\
85029\end{array}$ & $\begin{array}{l}\text { (602) } 465-7356 \\
\text { Mr. Matt Rupp }\end{array}$ & $\begin{array}{l}\text { Performance, reliability, and durability testing of } \\
\text { photovoltaic materials, components, and subsystems. } \\
\text { Six remote sites and a seventh planned }\end{array}$ \\
\hline $\begin{array}{l}\text { Franklin Research } \\
\text { Center (FRC) }\end{array}$ & $\begin{array}{l}20 \text { th and Parkway } \\
\text { Philadelphia, } \\
\text { Pennsylvenia } \\
19103\end{array}$ & $\begin{array}{l}\text { (215) } 448-1591 \\
\text { Mr. Charles Belsterling }\end{array}$ & $\begin{array}{l}\text { Non-profit. Facility size: } 19,000 \mathrm{~m}^{2} \text {. Experience } \\
\text { relative to tracking and control of electrical output } \\
\text { and utility interface. Some research relative to } \\
\text { development of thermal collectors }\end{array}$ \\
\hline $\begin{array}{l}\text { Structural } \\
\text { Dynamics Research } \\
\text { Corp. (SDRC) }\end{array}$ & $\begin{array}{l}200 \text { Eastman Drive } \\
\text { Milford, Ohic } 45515\end{array}$ & $\begin{array}{l}\text { (513) } 576-2400 \\
\text { Mr. Garth Wiley }\end{array}$ & $\begin{array}{l}\text { Facility size: } 800 \mathrm{~m}^{2} \text {. Mechanical and structural } \\
\text { engineering consulting company; primarily failure and } \\
\text { fatigue through analysis and testing }\end{array}$ \\
\hline Wyle Laboratories & $\begin{array}{l}7800 \text { Governors Dr. West } \\
\text { Huntsville, Alabama } \\
35807\end{array}$ & $\begin{array}{l}\text { (205) } 837-4411 \\
\text { Mr. David Christensen }\end{array}$ & $\begin{array}{l}\text { Environmental testing capabilities include acceler- } \\
\text { ated testing, power conditioner testing to } 27 \mathrm{~kW} \mathrm{DC} \text {; } \\
\text { load capability to } 110 \mathrm{~kW}\end{array}$ \\
\hline
\end{tabular}


Table 3-3. Systems Test Capabilities: Photovoltaics Program Centers

\begin{tabular}{|c|c|c|c|c|c|c|c|c|c|c|c|c|}
\hline \multirow[b]{2}{*}{ Facility } & \multirow{2}{*}{$\begin{array}{c}\text { Facility } \\
\text { Size }\end{array}$} & \multirow[b]{2}{*}{$\begin{array}{l}\text { Flat } \\
\text { Plate }\end{array}$} & \multirow[b]{2}{*}{ Concentrator } & Array & \multirow[b]{2}{*}{ Thermal } & \multicolumn{2}{|c|}{ Power Conditioner } & \multirow[b]{2}{*}{$\begin{array}{c}\text { Connection, } \\
\text { kVA }\end{array}$} & \multicolumn{2}{|c|}{ storage } & \multicolumn{2}{|r|}{ Load } \\
\hline & & & & $\begin{array}{l}\text { Tracking } \\
\text { Accuracy }\end{array}$ & & $\begin{array}{c}\text { Rating, } \\
\mathrm{kW}\end{array}$ & $\begin{array}{c}\text { Rating, } \\
\text { kVA }\end{array}$ & & Type & $\begin{array}{c}\text { Rating, } \\
\text { kWh }\end{array}$ & $\begin{array}{c}\text { Static, } \\
\mathrm{kW}\end{array}$ & $\begin{array}{c}\text { Reactive, } \\
\text { kVA }\end{array}$ \\
\hline $\begin{array}{l}\text { Jet } \\
\text { Propulsion } \\
\text { Laboratory }\end{array}$ & $\begin{array}{l}10 \text { acres } \\
\text { (RS, R, I). }\end{array}$ & Yes & 3500 Suns & $\begin{array}{l} \pm 0.05 \mathrm{deg} \\
\frac{ \pm}{2}-\mathrm{Axis}\end{array}$ & $\begin{array}{l}50 \mathrm{gpm} \\
\text { at } 150 \mathrm{psi}\end{array}$ & 10 & 10 & No & Batteries & 130 amp-h & Yes & Yes \\
\hline $\begin{array}{l}\text { Lewis } \\
\text { Research } \\
\text { Center }\end{array}$ & $\begin{array}{l}12,000 \mathrm{~m}^{2} \\
(\mathrm{RS})\end{array}$ & Yes & 100 Suns & - & - & 30 & $\begin{array}{l}30 \\
\pm 0.8 \mathrm{PF}\end{array}$ & 30 & $\begin{array}{l}\text { Batteries, } \\
\text { Redox }\end{array}$ & $\begin{array}{l}48 \\
10\end{array}$ & 50 & $\begin{array}{l}30 \text { Cap } \\
15 \text { Ind }\end{array}$ \\
\hline $\begin{array}{l}\text { MIT Lincoln } \\
\text { Laboratory }\end{array}$ & $\begin{array}{l}.750 \mathrm{~m}^{2} \\
(\mathrm{RS}, \mathrm{R}, \mathrm{I})\end{array}$ & Yes & 3 Suns & - & (ASHRAE) & 2.5 & 10 & 10 & $\begin{array}{l}\text { Batteries, } \\
\text { Flywheel }\end{array}$ & $\begin{array}{l}750 \\
\text { Experi- } \\
\text { mental }\end{array}$ & 10 & 3 \\
\hline $\begin{array}{l}\text { Sandia } \\
\text { National } \\
\text { Laboratories }\end{array}$ & $\begin{array}{l}930 \mathrm{~m}^{2} \\
(\mathrm{RS}, \mathrm{R} \\
(\mathrm{I}, \mathrm{CS})\end{array}$ & Yes & 1500 Sun 3 & $\pm 0.08 \mathrm{deg}$ & $\begin{array}{l}60 \mathrm{kBcu} / \mathrm{h} \\
\text { Cooling }\end{array}$ & 10 & $\begin{array}{l}180 \\
\pm 0.8 \mathrm{PF} \\
3 \phi\end{array}$ & 180 & Batteries & 24 & 150 & 228 \\
\hline
\end{tabular}




\section{Table 3-4. Collector Test Capabilities: Photovoltaics Program Centers}

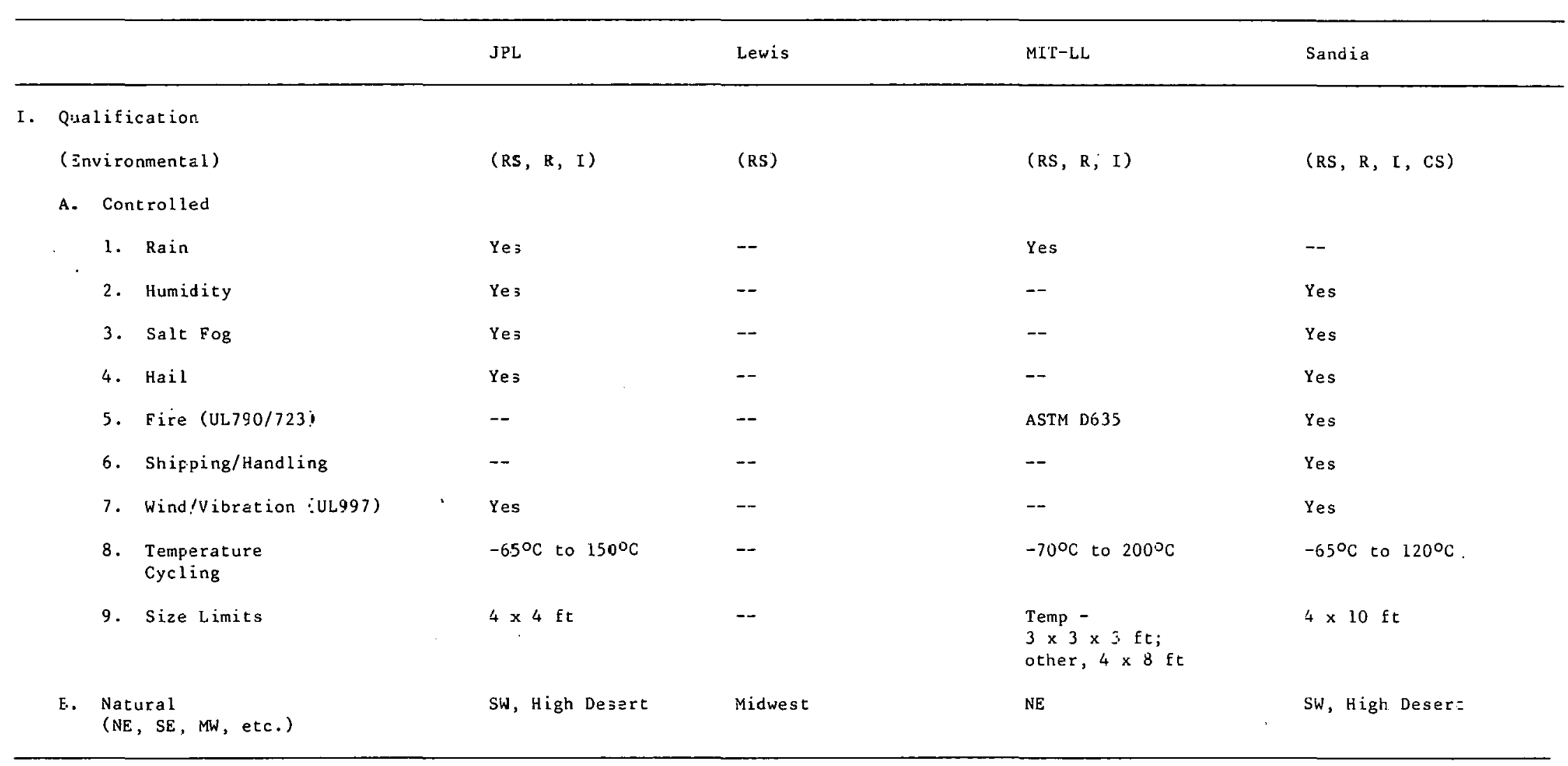


Table 3-4. (Cont'd) Collector Test Capabilities: Photovoltaics Program Centers

\begin{tabular}{|c|c|c|c|c|c|}
\hline & & JPL & Lewis & MIT-LL & Sandia \\
\hline \multicolumn{6}{|c|}{ II. Performance } \\
\hline \multirow[t]{12}{*}{ A. } & Capability & $(R S, R, I)$ & ' (RS) & $(\mathrm{RS}, \mathrm{R}, \mathrm{I})$ & $(\mathrm{RS}, \mathrm{R}, \mathrm{I}, \mathrm{CS})$ \\
\hline & 1. Flat Plate & Yes & Yes & Yes & Yes \\
\hline & 2. Concentrator (Suns) & 3500 & 100 & 3 & 1500 \\
\hline & 3. Tracking Accuracy & $\pm 0.05 \mathrm{deg}$ & -- & -- & $\pm 0.08 \mathrm{deg}$ \\
\hline & 4. Simulator (size) & $4 \times 8 \mathrm{ft}$ & $4 \times 8 \mathrm{ft}$ & $5 \times 5 \mathrm{ft}$ & -- \\
\hline & 5. Thermal & & . & & \\
\hline & a. Cooling & $\begin{array}{l}50 \mathrm{gpm} \text { at } \\
150 \mathrm{psi}\end{array}$ & -- & Yes & $60 \mathrm{k} \mathrm{Btu} / \mathrm{h}$ \\
\hline & b. Storage & -- & -- & $40 \mathrm{gal}$ & -- \\
\hline & c. Fluid Loop & -- & -- & $100^{\circ} \mathrm{C}, 1 \mathrm{gpm}$ & $90^{\circ} \mathrm{C}, 12 \mathrm{gpm}$ \\
\hline & d. ASHRAE & & · & & \\
\hline & i: Storage & -- & -- & -- & -- \\
\hline & ii. Collector & -- & -- & Yes & Yes \\
\hline
\end{tabular}


Table 3-L. (Cont'd) Collector Test Capabilities: Photovoltaics Program Centers

\begin{tabular}{|c|c|c|c|c|c|}
\hline & & jPL & Lewis & MLT-LL & Sandia \\
\hline \multirow{2}{*}{\multicolumn{6}{|c|}{$\begin{array}{l}\text { B. Measurement } \\
\text { 1. Simulator }\end{array}$}} \\
\hline & & & & & \\
\hline & a. Temperature (Module) & 巳es & Yes & Yes & Yes \\
\hline & b. Hot Box & $\begin{array}{l}\Rightarrow \times 4 \mathrm{ft},-65^{\circ} \mathrm{C} \\
\text { at } 150^{\circ} \mathrm{C}\end{array}$ & -- & $4 \times 4 \mathrm{ft}, 150^{\circ} \mathrm{C}$ & -- \\
\hline & $\begin{array}{c}\text { c. Irradiance } \\
\text {. }\end{array}$ & $150 \mathrm{MW} / \mathrm{cm}^{2}$ & $\begin{array}{l}\text { P.1 lsed, } \\
10^{4} \mathrm{NW} / \mathrm{cm}^{2} \\
\text { Steady, } \\
150 \mathrm{MW} / \mathrm{cm}^{2}\end{array}$ & $85-110 \mathrm{~mW} / \mathrm{cm}^{2}$ & $105 \mathrm{MW} / \mathrm{cm}^{2}$ \\
\hline \multicolumn{6}{|c|}{ 2. Insolation } \\
\hline & a. Dizect & les & Yes & Yes & Yes \\
\hline & b. Diffuse & ies & Yes & -- & -- \\
\hline & c. Total & Zes & Yes & Yes & Yes \\
\hline & d. UV & -- & -- & Yes & -- \\
\hline \multicolumn{6}{|c|}{ 3. IV curves } \\
\hline & a. Manual & Yes & Yes & Yes & -- \\
\hline & b. Automatic & ies & Yes & Yes & Yes \\
\hline \multicolumn{6}{|c|}{ 4. Load } \\
\hline & a. Dynamic Sweep & Auto and Manual & Manual & Auto and Manual & Auto and Manual \\
\hline & b. Static & Manual & yes & Yes & Yes \\
\hline
\end{tabular}


Table 3-5. Power Conditioner Test Capabilities: Photovoltaics Program Centers

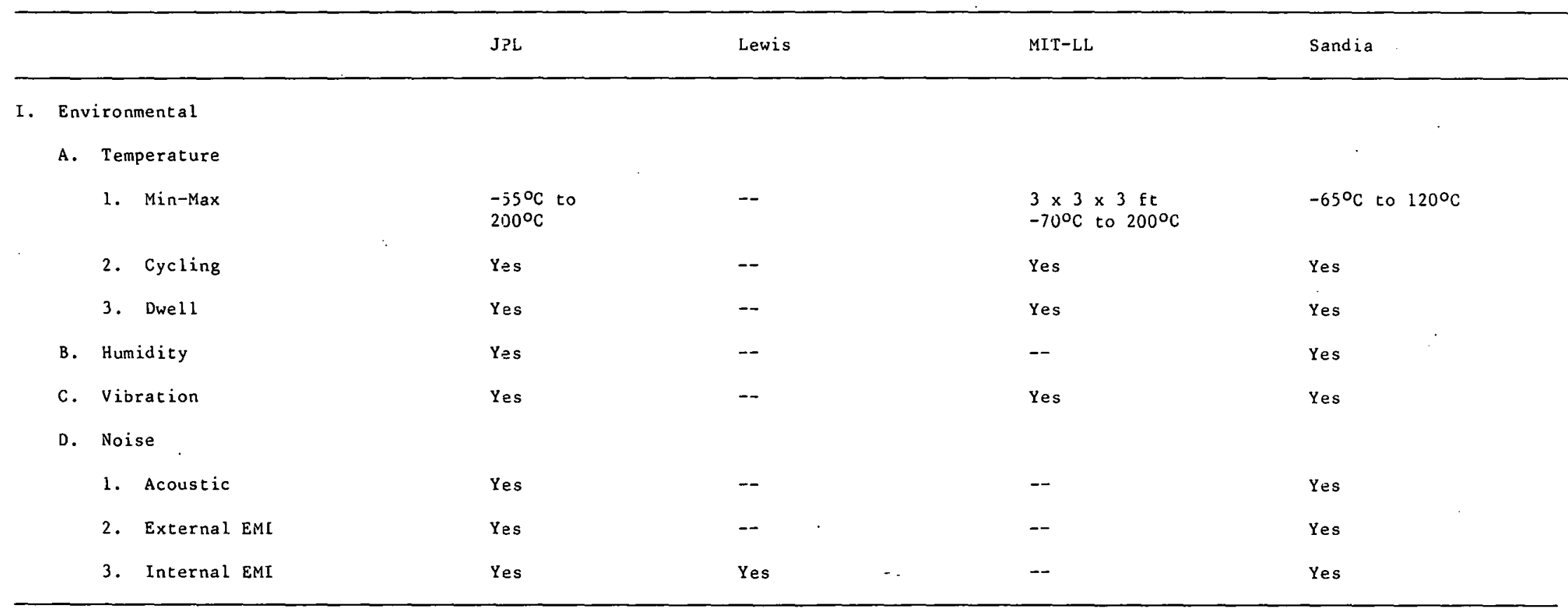


Table 3-5. (Cont'd) Power Conditioner Test Capabilities: Photovoltaics Program Centers

\begin{tabular}{|c|c|c|c|c|}
\hline & JPL & Lewis & MIT-LL & Sandia \\
\hline \multicolumn{5}{|l|}{ II. Performance } \\
\hline \multicolumn{5}{|l|}{ A. DC } \\
\hline 1. Rating & $10 \mathrm{~kW}, 400 \mathrm{~V}$ & $30 \mathrm{~kW}, 600 \mathrm{v}$ & $2.5 \mathrm{~kW}, 400 \mathrm{~V}$ & $10 \mathrm{~kW}, 375 \mathrm{v}$ \\
\hline 2. Switch Rating & $600 \mathrm{~V}: 100 \mathrm{amp}$ & $240 \mathrm{v}, 125 \mathrm{amp}$ & -- & $600 \mathrm{~V}, 100 \mathrm{amp}$ \\
\hline \multicolumn{5}{|l|}{ E. $\mathrm{AC}$} \\
\hline 1. Rating (kVA, V, PF) & $10,240,0.8$ & $30,240, \pm 0.8$ & $10,240,1$ & $180,440,0.8$ \\
\hline 2. Commutation & Line and Self & Line and Self & Line and Self. & Line and Self \\
\hline c. Load Variation & Yes & Yes & Yes & Yes \\
\hline D. Input Variation & Yes & Yes & Yes & Yes \\
\hline \multicolumn{5}{|l|}{ E. Functional Tests } \\
\hline 1. Short-Circuit & Yes & Yes & Yes & Yes \\
\hline 2. Lightning & Yes & -- & -- & Yes \\
\hline 3. Internal Switcting & Yes & Yes & Yes & Yes \\
\hline 4. External Switcting & Yes & Yes & Yes & Yes \\
\hline 5. Controls. & Yes & Yes & Yes & Yes \\
\hline 6. Temperature & Yes & Yes & Yes & Yes \\
\hline
\end{tabular}


Table 3-5. (Cont'd) Power Conditioner Test Capabilities: Photovoltaics Program Centers

\begin{tabular}{|c|c|c|c|c|}
\hline & JPL & Lewis & MIT-LL & Sandia \\
\hline \multicolumn{5}{|l|}{ III. Measurement } \\
\hline A. Array Simulation & $2 \mathrm{~kW}$ & -- & -- & $10 \mathrm{~kW}$ and $75 \mathrm{~kW}$ \\
\hline \multicolumn{5}{|l|}{ B. Load Simulation } \\
\hline 1. Static & $10 \mathrm{~kW}, 240 \mathrm{~V}$ & $50 \mathrm{~kW}, 250 \mathrm{v}$ & $10 \mathrm{~kW}, 240 \mathrm{~V}$ & $150 \mathrm{~kW}, 240 \mathrm{~V}$ \\
\hline 2. Reactive & $\begin{array}{l}\text { 5. } \mathrm{k} \mathrm{VA}, 240 \mathrm{~V} \\
\pm 0.8 \mathrm{PF}\end{array}$ & $\begin{array}{l}30 \mathrm{kVA} \text { Cap., } 15 \mathrm{kVA} \text { Ind., } \\
240 \mathrm{~V}, \pm 0.8 \mathrm{PF}\end{array}$ & -- & $\begin{array}{l}228 \mathrm{kVA}, 240 \mathrm{~V}, \\
\pm 0.5 \mathrm{PF}\end{array}$ \\
\hline 3. Overload & -- & -- & -- & -- \\
\hline 4. Incremental Load & Yes & Continuous kw & Continuous $\mathrm{kW}$ & $3.3 \mathrm{amp}, 1 \mathrm{~kW}$ \\
\hline 5. Wattmeters & Yes & Yes & Yes & Yes \\
\hline 6. Auto Data Rate & Yes & $5 \mathrm{kHz}$ & 12 channels $/ \mathrm{sec}$ & $14 / \mathrm{sec}$ \\
\hline
\end{tabular}




\section{Table 3-6. Storage Test Capabilities: Photovoltaics Program Centers}

\begin{tabular}{|c|c|c|c|c|}
\hline & JPL & Lewis & MIT-LL & Sandia \\
\hline \multicolumn{5}{|l|}{ I. Er.yironmental } \\
\hline \multicolumn{5}{|l|}{ A. Temperature } \\
\hline 1. Min-Max & $-55^{\circ} \mathrm{C}$ to $200^{\circ} \mathrm{C}$ & -- & -- & $-65^{\circ} \mathrm{C}$ to $200^{\circ} \mathrm{C}$ \\
\hline 2. Cycling & Yes & -- & -- & Yes \\
\hline 3. Dwell & Yes & -- & -- & Yes \\
\hline B. Water Loss & Yes & -- & Yes & Yes \\
\hline c. Hydrogen Accumslation & Yes & - & -- & -- \\
\hline \multicolumn{5}{|l|}{ II. Performance } \\
\hline A. Batteries & 130 aimp-h, $15 \mathrm{kWh}$ & $48 \mathrm{kWh}$ & $750 \mathrm{kWh}$ & $24 \mathrm{kwh}$ \\
\hline 1. Constant Discharge & -- & -- & $2.5 \mathrm{~kW}, 20 \mathrm{amp}$ & $24 \mathrm{~kW}, 100 \mathrm{amp}$ \\
\hline 2. Constant Charge & $200 \mathrm{v}, 150 \mathrm{amp}$ & 130 & $130 \mathrm{v}, 150 \mathrm{amp}$ & $\dot{320} \mathrm{v}, 10 \mathrm{amp}$ \\
\hline E. Flywheel & -- & -- & $36-i n . d i a$ & -- \\
\hline C. Pumped Fiydro & -- & -- & -- & -- \\
\hline [. Other & -- & Redox, $10 \mathrm{kWh}$ & -- & -- \\
\hline \multicolumn{5}{|l|}{ III. Measurement } \\
\hline (volts, amps, shunts) & Yes & Yes & Yes & Yes \\
\hline
\end{tabular}


Table 3-7. Collector Test Capabilities: Private Laboratories

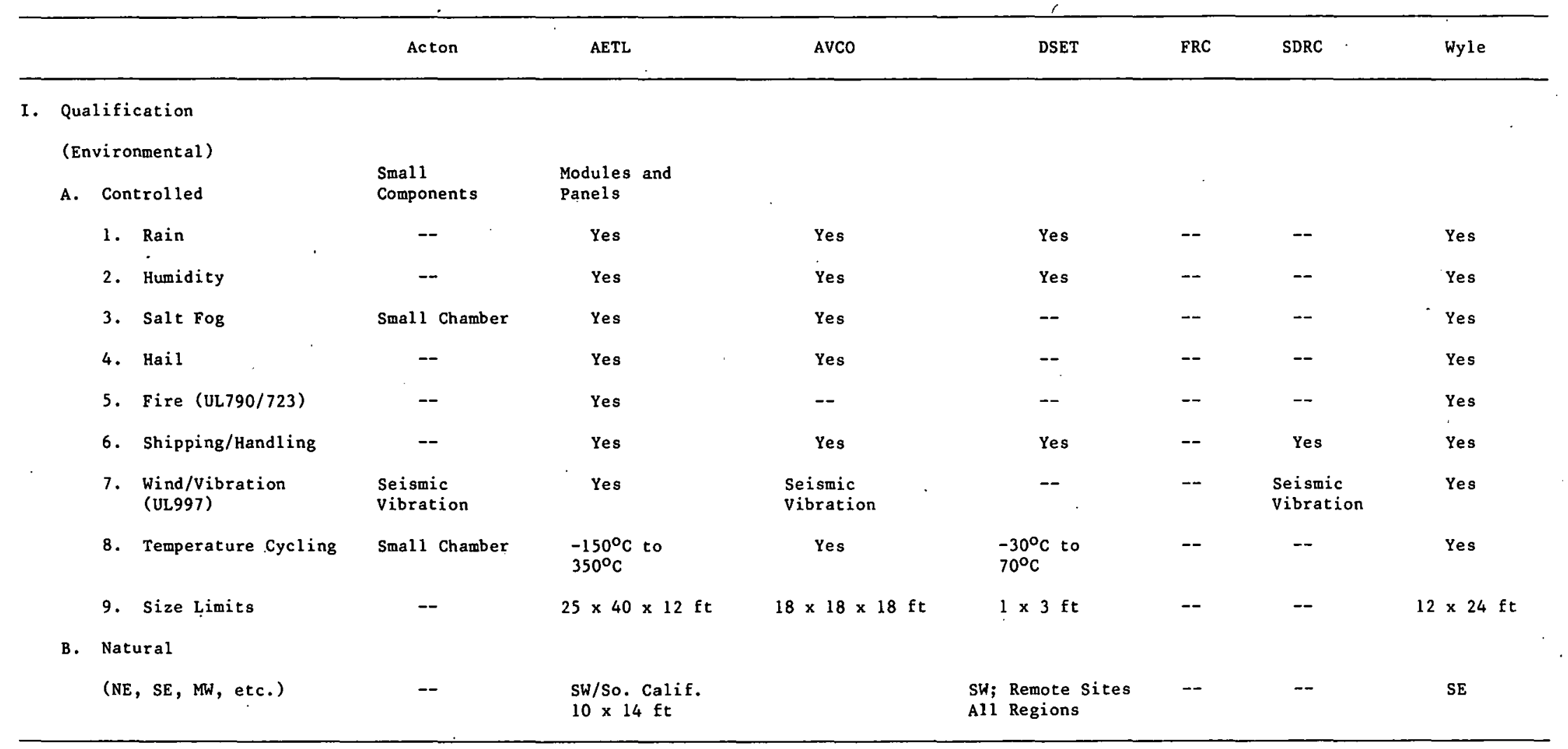


Table 3-7. (Cont'd) Collector Test Capabilities: Private Laboratories

\begin{tabular}{|c|c|c|c|c|c|c|c|}
\hline & Acton & AETL & AVCO & DSET & FRC & SDRC & Wyle \\
\hline \multicolumn{8}{|l|}{ II. Per formance } \\
\hline \multicolumn{8}{|l|}{ A. Capability } \\
\hline 1. Flat Plate & -- & Yes & -- & Yes & -- & -- & Yes \\
\hline 2. Concentrator (Suns) & -- & -- & No & 100 & -- & -- & 60 \\
\hline 3. Tracking Accuracy & -- & -- & -- & $\pm 0.1^{\circ}$ & -- & -- & $\pm 1.25 \mathrm{deg}$ \\
\hline \multicolumn{7}{|l|}{ 5. Thermal } & $4 \times 8 \mathrm{ft}$ \\
\hline a. Cooling & -- & Yes & Yes & $25 \mathrm{kw}$ & -- & -- & $20 \mathrm{~kW}$ \\
\hline b. Storage & -- & Yes & -- & $540 \mathrm{MJ} / \mathrm{day}$ & $80 \mathrm{gal}$ & -- & $300 \mathrm{gal}$ \\
\hline c. Fluid Loop & -- & Yes & -- & $\begin{array}{l}10^{\circ} \mathrm{C} \text { to } \\
316^{\circ} \mathrm{C} \\
0-10 \mathrm{gpm}\end{array}$ & $93^{\circ} \mathrm{C}$ & -- & $\begin{array}{l}4^{\circ} \mathrm{C} \text { to } \\
315^{\circ} \mathrm{C}, \\
10 \mathrm{gpm}\end{array}$ \\
\hline d. ASHRAE & -- & Yes & - & $\begin{array}{l}93-77,94-77 \\
95-81,96-80\end{array}$ & -- & - & -- \\
\hline i. Storaze & -- & Yes & -- & Yes & -- & -- & Yes \\
\hline ii. Colle =tor & - & Yes & -- & Yes & -- & -- & Yes \\
\hline
\end{tabular}


Table 3-7. (Cont'd) Collector Test Capabilities: Private Laboratories

\begin{tabular}{|c|c|c|c|c|c|c|c|c|}
\hline & & Acton & AETL & Avco & DSET & FRC & SDRC & Wyle \\
\hline \multirow{16}{*}{ B. } & Measurement & & & & & & & \\
\hline & 1. Simulator & & & & & & & \\
\hline & a. Temperature (Module) & -- & Yes & -- & Yes & -- & -- & Yes \\
\hline & b. Hot Box & -- & Yes & $. \quad--$ & $4 \times 8 \times 1 \mathrm{ft}$ & -- & -- & $4 \times 8 \times 2 \mathrm{ft}$ \\
\hline & c. Irradiance & -- & Yes & -- & $125 \mathrm{MW} / \mathrm{cm}^{2}$ & -- & -- & $100 \mathrm{~W} / \mathrm{cm}^{2}$ \\
\hline & 2. Insolation & & & & & & & \\
\hline & a. Direct & -- & Yes & -- & Yes & -- & -- & Yes \\
\hline & b. Diffuse & -- & Yes. & -- & Yes & -- & -- & Yes \\
\hline & c. Total & -- & Yes & -- & Yes & -- & -- & Yes \\
\hline & d. uv & -- & Yes & -- & Yẹs & -- & -- & Yes \\
\hline & 3. IV Curves & & & & & & & \\
\hline & a. Manual & -- & Yes & -- & -- & -- & -- & -- \\
\hline & b. Automat ic & -- & Yes & -- & Yes & -- & -- & Yes \\
\hline & 4. Load & & & & & & & \\
\hline & a. Dynamic Sweep & -- & Yes & -- & Yes & -- & -- & Yes \\
\hline & b. Static. & -- & Yes & -- & Yes & -- & -- & Yes \\
\hline
\end{tabular}


Table 3-3. Power Conditioner Test Capabilities: Private Laboratories

\begin{tabular}{|c|c|c|c|c|c|c|c|c|c|}
\hline & & . & Acton & AETL & AVCO & DSET & FRC & SDRC & Wyle \\
\hline \multirow[t]{11}{*}{ I. } & \multicolumn{9}{|c|}{ Envi ronmental } \\
\hline & \multirow[t]{4}{*}{ A. } & \multicolumn{8}{|l|}{ Temperature } \\
\hline & & 1. Min-Max & -- & $\begin{array}{l}-70^{\circ} \mathrm{C} \text { to } \\
175^{\circ} \mathrm{C}\end{array}$ & $\begin{array}{l}-73^{\circ} \mathrm{C} \text { to } \\
538^{\circ} \mathrm{C}\end{array}$ & -- & Yes & -- & $\begin{array}{l}-85^{\circ} \mathrm{C} \text { to } \\
150^{\circ} \mathrm{C}\end{array}$ \\
\hline & & 2. Cycling & -- & Yes & Yes & -- & Yes & -- & Yes \\
\hline & & 3. Dwe1l & -- & Yes & Yes & -- & Yes & -- & Yes \\
\hline & B. & Humidity & -- & Yes & Yes & -- & Yes & -- & Yes \\
\hline & c. & vibration & -- & Yes & Yes & -- & Yes & -- & Yes \\
\hline & \multicolumn{9}{|c|}{ D. Noise } \\
\hline & & 1. Acoustic & Yes & Yes & -- & -- & Yes & -- & Yes \\
\hline & & 2. External EMI & Yes & Yes & -- & - & Yes & -- & -- \\
\hline & & 3. Internal. EMI & Yes & Yes & -- & -- & -- & -- & -- \\
\hline
\end{tabular}


Table 3-8. (Cont'd) Power Conditioner Test Capabilities: Private Laboratories

\begin{tabular}{|c|c|c|c|c|c|c|c|c|}
\hline \multicolumn{9}{|c|}{ II. Performance } \\
\hline & 1. Rating & -- & -- & -- & -- & -- & -- & $27 \mathrm{~kW}, 90 \mathrm{v}$ \\
\hline & 2. Switch Rating & -- & Yes & -- & -- & Yes & -- & $90 \mathrm{v}, 300 \mathrm{amp}$ \\
\hline \multirow{8}{*}{$\begin{array}{l}C \\
D\end{array}$} & 1. Rating & -- & -- & -- & -- & -- & -- & $\begin{array}{l}90 \mathrm{kVA}, 480 \mathrm{~V} \\
\pm 0.8 \mathrm{PF}\end{array}$ \\
\hline & 2. Commutation & -- & Line and Self & -- & -- & -- & -- & Line and Self \\
\hline & Load Variation & -- & Yes & -- & -- & -- & -- & Yes \\
\hline & Input Variation & - & Yes & - & -- & -- & -- & Yes \\
\hline & 3. Internal Switching & -- & Yes & -- & -- & -- & -- & Yes \\
\hline & 4. External Switching & -- & Yes & -- & -- & -- & - & Yes \\
\hline & 5. Controls & -- & Yes & -- & -- & -- & -- & Yes \\
\hline & 6. Temperature & Small Chamber & Yes & -- & - & -- & -- & Yes \\
\hline
\end{tabular}


Table 3-8. (Cont'd) Power Conditioner Test Capabilities: Private Laboratories

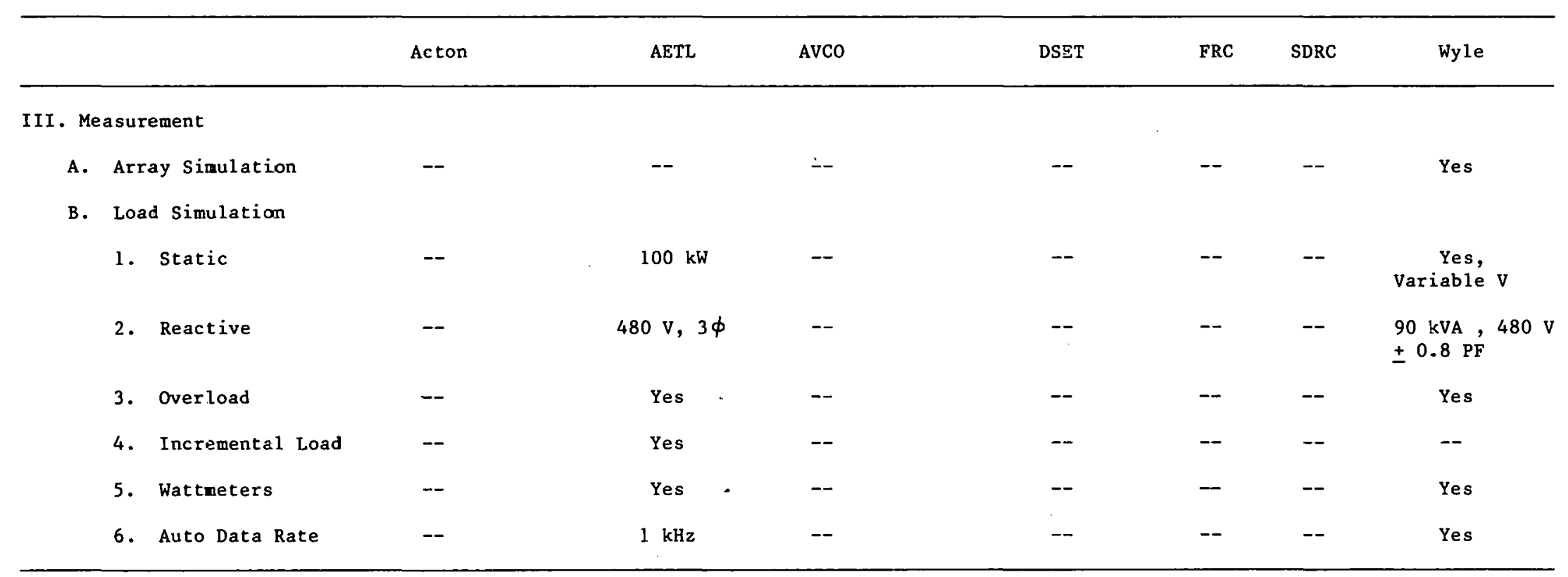

